\title{
Komplementárne pôsobenie etického a právneho normatívneho systému
}

\section{The Complementarity of Ethical and Legal Normative System}

\author{
Ondrej Mital*
}

\begin{abstract}
Abstrakt
Zobladñovanie etickébo aspektu praxe verejnej správy je dôlę̧itou súcast'ou správy veci verejných v demokratických spoločnostiach. Predkladaná śtúdia sa pokúšsa obohatit’ diskusiu týkajúcu sa významu etických noriem vo sfére verejnej správy. Súčasne štúdia skúma, za vyư̌itia deduktivno-induktivneho postupu, výbody a limity etických noriem ako regulátora správania sa zamestnancov verejnej správy v podmienkach Slovenskej republiky. Úvodná čast'je venovaná najdiskutovanejšm názorom, ktoré súvisia so skúmanou problematikou. Klúcová čast' stúdie upriamuje pozornost' na aktuálnu prax, pricom dôraz je kladený na etické normy prijaté v rámci štátnej správy a územnej samosprávy. Za blavný prínos štúdie možno považovat' zistenie, že etické normy mỗu byt’ významným faktorom, prostrednictvom ktorého je možné ouplyvnit' správanie sa zamestnancov a mali by byt' vyư̌ivané ako komplementárny a dodatočný regulátor popri platnej a účinnej legislative. Záver predkladanej štúdie obsabuje diskusiu zameranú na predpoklady a odporúčania súvisiace s potenciálnym kvalitatívnym zlepšením skúmanej problematiky.
\end{abstract}

Klíčová slova

Etika vo verejnej správe; etický normativny systém; právny normativny systém; etické kódexy; komplementárne pôsobenie.

\begin{abstract}
Considering ethical aspect of public administration practice is an essential part of public administration in democratic countries. The presented study tries to enrich discussion about the importance of ethical norms in the sphere of public administration. Besides that, the study examines, with the help of deductive and inductive method, the benefits and limits of ethical norms as a regulator of public administration employee's behaviour in the conditions of Slovak. Republic. The introductory part of presented text is devoted to the most discussed theoretical opinions linked to the examined issue. The core part of study concentrates its attention on the current state of practice with emphasize on ethical norms adopted by state administration and local self-government units. The main benefit of this paper is based on the finding that ethical norms could be important factor, which could infuence the behaviour of employees and should be used as a complementary and additional regulator along with the legislative. Finally, the study ends with a discussion of the assumptions and suggestion connected with potential of qualitative improvement of examined issue.
\end{abstract}

\section{Keywords}

Public Administration Ethics; Ethical Normative System; Legal Normative System; Codes of Ethics; Complementary Effect.

\footnotetext{
* PhDr. Ondrej Mital', PhD., výzkumný pracovník, Fakulta verejnej správy, Univerzita Pavla Jozefa Šafárika v Košiciach, Slovenská republika / Researcher, Faculty of Public Administration, Pavol Jozef Šafárik University in Košice, Slovak Republic / E-mail: ondrej.mital@upjs.sk / ORCID: 0000-0003-3773-8714
} 


\section{Úvod}

Súčasná spoločnost' je vd’aka svojej komplexnosti, dynamickosti a zdanlivo nekonečnému rozmachu spútaná niekedy až príliš vel'kým množstvom predpisov, pravidiel či obmedzení. Schopnost' l'udstva komplikovaným spôsobom riešit’ jednoduché záležitosti trefne popisuje D. Graeber slovami, že pokial’ sa vytvorí byrokratická štruktúra majúca za úlohu vysporiadat' sa s nejakým objektívne existujúcim problémom, táto začne vytvárat' d'alšie problémy, ktoré možno riešit' len d’alšími byrokratickým prostriedkami. ${ }^{1}$ Napriek tomu možno hovorit' o potrebe cielenej regulácie l’udskej činnosti, pretože obzvlášt' v oblasti správy veci verejných sa to zdá byt' za účelom dosiahnutia verejných záujmov priam nevyhnutné. Rovnako ako v iných oblastiach spoločenského života, tak aj vo verejnej správe možno identifikovat' dvojdimenzionálnost', ktorá nadobúda atribúty správnosti alebo nesprávnosti. Existujú situácie, v rámci ktorých dokážeme jasne rozlíšit' čo je správne a čo je nesprávne, ale komplexnost' súčasnej spoločnosti spôsobuje miešanie týchto protipólov a zahmlievanie rozdielov medzi týmito zdanlivo odlišnými antagonizmami. ${ }^{2}$ Pre sféru verejnej správy je prioritne správne a želatel'né to, čo je obsiahnuté v platných a účinných právnych predpisoch. Právo je ako normatívny systém relatívne samostatné a autonómne, pričom jeho spoločenská rezonancia, efektivita a legitimita prioritne závisí na jazykovej interpretácii a konceptuálnej schemantizácii. ${ }^{3}$ Zároveň je však potrebné vnímat' existenciu iných normatívnych systémov. Právne, morálne, religiózne a iné typy spoločenských noriem totiž predstavujú prostriedky, prostredníctvom ktorých je uskutočňovaná regulácia správania sa a interakcie l’udí, pričom tieto $\mathrm{v}$ konečnom dôsledku vyjadrujú objektívnu potrebu usporiadania vzt'ahov členov spoločnosti prostredníctvom nevyhnutných pravidiel. ${ }^{4}$ Mimo hraníc Slovenska je v teoretickej aj praktickej rovine často diskutovaný význam etického normatívneho systému. Etika je normatívny systém, ktorý je vd’aka svojej rôznorodosti a komplexnosti plne aplikovatel'ný na súčasnú spoločnost'. ${ }^{5}$ Etický normatívny systém by v načrtnutom zmysle nemal byt' vnímaný ako produkt d’alších pravidiel, ale skôr ako zhmotnenie dlhoročných overených všel'udských etických hodnôt a etických princípov, ktoré je potrebné aplikovat' vo svetle súčasných problémov praxe verejnej správy.

1 GRAEBER, David. Utopie Pravidel: O technologii, stupidite a skeryté prtą̌livosti byrokracie. Praha: Prostor, 2017, 284 s. ISBN 978-80-7260-352-7.

2 FISHER, Anthony. Bioethics after Finnis. In: KEOWN, John a Robert P. GEORGE (eds.). Reason, Morality, and Law: The Philosophy of John Finnis. Oxford: Oxford University Press, 2015, 615 s. ISBN 978-0-19-873810-7.

3 HARVÁNEK, Jaromír a Jan STEJSKAL. Stát a právo v éře postmoderní komunikace. In: Casopis pro právní védu a praxi, Brno: Masarykova univerzita, Právnická fakulta, 2010, roč. 18, č. 2, s. 111-117. Dostupné z: https://journals.muni.cz/cpvp/article/view/6484

4 KLÍMA, Karel. Teorie veréjné moci (vládnutí). 3. vyd. Praha: Wolters Kluwer ČR, $2016,428 \mathrm{~s}$. ISBN 978-80-7552-331-0.

5 SINGER, Peter. Practical ethics. 3. ed. Cambridge: Cambridge University Press, 2011, 356 s. ISBN 978-0-321-70768-8. 
Ambíciou predkladanej štúdie je prispiet' do ambivalentnej diskusie týkajúcej sa významu a postavenia noriem etického charakteru vo sfére verejnej správy. Domáci a zahraniční odborníci upriamujú svoju pozornost' na prieniky a komplementárnost’ pôsobenia etického a právneho normatívneho systému. Vychádzajúc z doposial’ uvedeného bola stanovená nasledovná výskumná otázka: Aké sú výhody a limity komplementárneho pôsobenia noriem etického charakteru ako regulátora správania sa zamestnancov pre oblast' správy veci verejných v podmienkach Slovenskej republiky. Nadväzne sa stanovená hypotéza opiera o tvrdenie, že etické normy disponujú potenciálom regulovat' správanie sa ich adresátov. Predkladaná štúdia sa zároveň pokúša poskytnút' odpovede na parciálne výskumné otázky: Aký je stav normatívneho rozmeru zohl’adňovania etického aspektu aktuálnej praxe vo verejnej správe? Akým spôsobom sú koncipované etické kódexy vo verejnej správe na Slovensku? Ako možno zlepšit’ aktuálnu prax zohl’adňovania etického aspektu vo verejnej správe v podmienkach Slovenskej republiky?

Súčasne je potrebné poznamenat', že pozornost' predkladanej štúdie bude upriamená prioritne na štátnu správu a územnú samosprávu. Kl’účovou čast’ou vypracovania štúdie je analýza etických kódexov regulujúcich správanie sa zamestnancov vybranej oblasti verejnej správy. Predmetom analýzy budú normy etického charakteru, ktoré sú riadnym spôsobom zverejnené a vol'ne prístupné širokej verejnosti. Táto podmienka je totiž nevyhnutným predpokladom realizácie dohladu verejnosti nad dodržiavaním stanovených etických požiadaviek. Súčast’ou spracovania predkladanej štúdie je aj práca s relevantnými právnymi predpismi. Využitím induktívno-deduktívneho prístupu sa predkladaný text pokúša v jeho závere formulovat’ odporúčania v zmysle stanovenej výskumnej otázky.

Aktuálnost' skúmanej problematiky je reflektovaná v teoretickej rovine predovšetkým zahraničnými odborníkmi, kde je vel’mi často diskutovaná v spojitosti s transparentnost’ou vo verejnej správe, etickým pracovným prostredím, etickou kompetentnost'ou jednotlivcov alebo je vnímaná v kontexte mechanizmov boja proti korupcii. Opodstatnenost' vedeckého bádania zameraného na normatívny rozmer zohl'adňovania etického aspektu správy veci verejných je podporená existenciou a reálnym uplatňovaním noriem etickej povahy vo vyspelých demokraciách, ako aj na platforme nadnárodných inštitúcií svetového alebo európskeho charakteru. Zámerom predkladaného textu je preto predovšetkým v teoretických súvislostiach rozpracovat’ perspektívy a východiská smerujúce k obohateniu diskusie týkajúcej sa predmetnej interdisciplinárnej problematiky.

\section{Význam komplementárneho pôsobenia etického a právneho normatívneho systému}

Očakávania týkajúce sa promptnosti reakcií na meniace sa prostredie sú v súčasnosti zo strany občana vel'ké, avšak v niektorých prípadoch je nutné poznamenat', že aj oprávnené. Zmeny po roku 1989 so sebou priniesli aj problémy, o ktorých diskutuje odborná 
ale aj laická verejnost'. ${ }^{6}$ Ak chce verejná správa plnit’ účel, na ktorý bola zriadená, musí reflektovat' výzvy nastol'ované spoločnost'ou. Organizácie verejnej správy sú na druhej strane limitované platnou a účinnou legislatívou, pretože s odvolaním sa na text Ústavy Slovenskej republiky môžu štátne orgány konat’ iba na základe ústavy, v jej medziach a v rozsahu a spôsobom, ktorý ustanoví zákon. Úloha zamestnanca verejnej správy býva v kontinentálnej Európe zakotvená v zákonoch, ktoré sú spravidla prostredníctvom vnútorných predpisov bližšie konkretizované. Preto je právo ako normatívny systém bytostne s verejnou správou prepojené. Z tohto dôvodu možno v kontexte skúmanej problematiky za klúčové považovat' právne normy, ktorými sú zákon číslo 55/2017 Z. z. o štátnej službe a o zmene a doplnení niektorých zákonov (d’alej len zákon o štátnej službe) a zákon číslo 552/2003 Z.z. o výkone práce vo verejnom záujme (d’alej len zákon o výkone práce vo verejnom záujme). Súčasne je však potrebné mat’ na zreteli postavenie zákona číslo 311/2001 Z.z. Zákonník práce (d’alej len Zákonník práce). Na štátnozamestnanecké vzt’ahy sa použije Zákonník práce, len ak to ustanovuje zákon o štátnej službe a na pracovnoprávne vzt'ahy zamestnancov pri výkone práce vo verejnom záujme sa vzt’ahuje Zákonník práce len ak to stanoví zákon o výkone práce vo verejnom záujme alebo osobitný predpis. ${ }^{8}$

Z pohl'adu skúmanej problematiky je potrebné znova zdôraznit', že v teoretickej aj praktickej rovine je odborníkmi často diskutovaný význam etického normatívneho systému. Etika sa odlišuje od iných regulatívnych systémov v tom, že je do určitej miery samoregulačný, pretože by mal byt' zdiel'aný a spoluvytváraný členmi konkrétnej spoločnosti. Komplementárne pôsobenie právneho a etického normatívneho systému možno charakterizovat' ako stav, ktorý je pre súčasné vyspelé demokracie typický. ${ }^{10}$ Praktickú aplikáciu na postkomunistické spoločnosti ponúkol už dávnejšie český právnik a sociológ J. Přibáň, podl’a ktorého tieto krajiny po zmene režimu uprednostňovali dlhú dobu výlučne legálne a spravodlivost' trestajúce prostriedky aby zistili, že takéto nástroje podl’a jeho názoru dokonca zlyhávajú. ${ }^{11}$ Aj ked’ možno povedat', že ide o krajne negativistický pohl’ad, je zložité zhodnotit', či v súčasnosti došlo k zrejmým zmenám. Nadväzne možno

6 ŽUPOVÁ, Eliška. Vzdelanie starostov obcí na Slovensku a problematika odbornosti v územnej samospráve. In: Sociology and Society, Nitra: Univerzita Konštantína Filozofa v Nitre, Filozofická fakulta, 2017, roč. 2 , č. 2 , s. $24-41$.

7 HENDRYCH, Dušan a kol. Správni věda: Teorie veřejné správy. 3. vyd. Praha: Wolters Kluwer, a. s., 2014, 244 s. ISBN 978-80-7478-561-0.

8 ŽOFČINOVÁ, Vladimíra. Pracovnoprávne vątaby vo verejnej správe. Košice. Univerzita Pavla Jozefa Šafárika v Košiciach, 2013, 160 s. ISBN 978-80-8152-064-8.

9 BRODEUR, Magaly. Public Policy Analysis and Management at the Crossroads: An Epistemological Investigation of Ethics and Public Actions. In: CONTEH, Charles a Ian ROBERGE (eds.). Canadian Public Administration in the 21st Century. Boca Raton: CRC Press, 2016, s. 173-188. ISBN 978-1-4665-9172-1.

10 BILASOVÁ, Viera. Vplyv integrácie a globalizácie na etiku verejnosti na Slovensku. In: KRÁL’OVÁ, L’uba (eds.). Genéza a tvorba verejnej politiky na Slovensku. Prešov: KM-Systém, 2009, s. 239-257. ISBN 978-80-85357-07-3.

11 PŘIBÁN, Jiří. 2001. Právo a politika konverzace. Praha: G plus G, 2001, 110 s. ISBN 80-86103-36-6. 
využit' myšlienku R. Gefferta pojednávajúcu o tom, že žijeme v dobe, kedy je preceňovaný význam práva, ktoré je povyšované do pozície absolútneho a jediného správneho normatívneho systému. ${ }^{12}$ Nevyhnutnost' komplementárneho pôsobenia oboch normatívnych systémov možno zdôraznit' aj slovami M. Duranteho v tom zmysle, že jednotlivé systémy sa dostávajú do vzájomnej interakcie, prelínajú sa a v niektorých prípadoch už právne termíny musia byt' vysvetl'ované za pomoci iných normatívnych systémov, pričom tento fakt je hlavným dôvodom prečo nemôže právny normatívny systém v 21. storočí existovat' a pôsobit' samostatne. ${ }^{13}$

Zo strany verejnosti sa objavujú požiadavky, ktoré legislatíva síce obsahuje, právna teória ich dokáže uspokojivo vyargumentovat', ale v plnej miere sú najlepšie interpretovatel'né práve prostredníctvom subdisciplíny aplikovanej etiky, ktorou je etika verejnej správy. Predovšetkým ide o oblast' boja s korupciou, mobing na pracovisku, konflikt záujmov, prijímanie darov a iných výhod, požiadavky na zvyšovanie transparentnosti alebo zabezpečenie dodržiavania vysokých štandardov integrity a osobnej zodpovednosti. Uvedený demonštratívny výpočet požiadaviek, ktoré výrazne napomáhajú fungovaniu právneho rozmeru činnosti verejnej správy je dôslednejšie popísaný práve odborníkmi, ktorí sa dlhodobo venujú problematike prieniku verejnej správy a etiky. Vd’aka tomu dokáže právo plnit' svoje spoločenské funkcie, a preto by mal štát podporovat' morálnu obnovu spoločnosti a povýšit' morálne a etické normy na úroveň partnerského vzt'ahu k právu. ${ }^{14} \mathrm{Na}$ tomto mieste je potrebné dodat', že uvedené myšlienky nemožno vnímat' v zmysle znižovania významu legislatívy, jej postavenia a úlohy v súčasnej spoločnosti a praxi verejnej správy. Etický normatívny systém by v tomto zmysle mal pôsobit' ako doplnok prameniaci predovšetkým z overených l'udských hodnôt, ktorých pretrvanie možno vnímat' vo vzt’ahu k budúcemu rozvoju spoločnosti pozitívne.

Súčasne možno v tomto zmysle argumentovat' naliehavost'ou vytvorenia a následnou aplikáciou etických hodnôt, princípov a štandardov, vd'aka ktorým by mohla byt' dosiahnutá vyššia flexibilita, zlepšenie individuálneho prístupu, dostupnost’ informácií a vyššia transparentnost'. ${ }^{15}$ Existencia súboru vhodných a dôsledne spracovaných etických štandardov, pomocou ktorých je možné predchádzat' etickým zmätkom, zastavit' profesijnú

12 GEFFERT, Richard. Postmoderná civilizácia a fatamorgána l’udských práv s osobitným zretel’om na sociálne práva. Ešte stále kráčaš, demokracia? In: EŠTOK, Gabriel, Richard GEFERT a Renáta BZDILOVÁ (eds.). L’udské práva: Kam kráčaš demokracia. Košice: Univerzita Pavla Jozefa Šafárika v Košiciach, 2015, s. 97-104. ISBN 978-80-8152-380-9.

13 DURANTE, Massimo. Ethics, Law and the Politics of Information: A Guide to the Philosophy of Luciano Floridi. Springer: Dordrecht, 2017, 223 s. ISBN 978-94-024-1148-5.

14 KRÁLIK, Jozef a Ján KÚTIK. Kontrolný systém a jeho subsystémy vo verejnej správe. Plzeň: Aleš Čeněk, 2013, 216 s. ISBN 978-80-7380-482-4.

15 KVASNICOVÁ, Erika. Etika verejnej správy. In: FOBELOVÁ, Daniela (eds.). Profesijná etika a prax. Banská Bystrica: Fakulta humanitných vied Univerzity Mateja Bela v Banskej Bystrici, 2008, s. 81-101. ISBN 978-80-8083-658-0. 
eróziu, zabránit’ znižovaniu motivácie a súčasne zamedzit' znižovaniu dôvery a legitimity zo strany verejnosti vo verejnú správu sa javí ako nevyhnutná. ${ }^{16}$

Možno však etické kódexy považovat' len za d’alší písaný súbor pravidiel, ktorý stanovuje limity správania sa, konania a rozhodovania jednotlivcov určitej organizácie, respektíve súboru organizáciî? Normy etického charakteru sú do značnej miery vyjadrením určitej prináležitosti $\mathrm{k}$ princípom a pravidlám $\mathrm{v}$ nich obsiahnutých. V tomto zmysle možno len súhlasit' s názorom M. S. Frankela o tom, že kódexy stelesňujú kolektívne svedomie profesie a sú určitým svedectvom sebaurčenia skupiny v kontexte morálnej dimenzie. ${ }^{17}$ Tento fakt je podporený dôležitým, ale nie až tak často vyskytujúcim sa procesom. Ide o deklarovanie alebo konštatovanie, že znenie normy etického charakteru bolo prerokované so zástupcami zamestnancov, respektíve so samotnými zamestnancami. Kódexy, ktoré obsahujú tento typ deklarácie možno z pohl’adu zohl'adňovania a riadenia etického aspektu považovat' v kontexte fungovania demokratickej spoločnosti za tie z najdokonalejších. V plnej miere totiž reflektujú podstatu etickej normy, ktorá je dodržiavaná konkrétnou skupinou jednotlivcov a v ideálnom prípade nepôsobí represívne, ale prevažne preventívne.

Súčasná spoločnost’ a zároveň aj verejná správa, ktorá je jej súčast’ou sú charakteristické komplexnými interakciami medzi verejnou správou a rôznymi entitami. V tomto zmysle je legislatíva pre verejnú správu kl’účová. Avšak, dnešná spoločnost' je charakteristická aj inými trecími plochami, medzi ktoré možno jednoznačne zaradit' etický aspekt spoločnosti. Podobne aj vo verejnej správe dochádza k situáciám, ktoré síce z legálneho pohl’adu sú jednoznačné, ale z hladiska iných normatívnych systémov je potrebné ich vnímat' v rôznych kontextoch. Práve v tomto zmysle možno identifikovat' nenahraditel'nost' komplementárneho pôsobenia etických noriem vo vzt'ahu k platnej a účinnej legislatíve. Etické kódexy teda nemožno považovat' len za d’alší súbor pravidiel a v konečnom dôsledku majú v načrtnutom zmysle nenahraditel'ný význam.

Vzhl'adom na doposial' uvedené možno len súhlasit' s odborníkmi na predmetnú problematiku, že spracovanie etických kódexov je v podmienkach verejnej správy najčastejšie vyskytujúcim sa nástrojom etického manažmentu. ${ }^{18}$ Etické kódexy majú ambíciu riešit'

16 HAQUE, Shamsul M. Contemporary Trends and Dilemmas of Administrative Ethics in the Developing World. In: DE VRIES Michiel S. a Pan Suk KIM (eds.). Value and Virtue in Public Administration: A Comparative Perspective, 2011, s. 169-185. ISBN 978-0-230-23647-9.

17 FRANKEL, Mark S. Professional Codes: Why, how, and with what impacts? In: Journal of Business Ethics, 1989 , roč. 8, č. 2-3, s. 109-115.

18 DYCK, Bruno a Mitchell J. NEUBERT. Management: Current Practices and New Directions. Boston: Houghton Mifflin Harcourt Publishing Company, 2010, 624 s. ISBN 978-0-618-83204-0; LEWIS, Carol W. Ethics Codes and Ethics Agencies: An Implementation. In: FREDERICKSON, George H. (eds.). Ethics and Public Administration. New York: Routledge, 2015, s. 136-157. ISBN 978-1-563-24097-3; ONDROVÁ, Drahomíra. Ethics, law and ethical conduct of behavior. In: CHMELÍK, Ján (ed.). Konsenzus v práve. Banská Bystrica: Belianum, 2013, s. 170-177. ISBN 978-80-557-0523-1; MENZEL, Donald C. Ethics Management for Public and Nonprofit Managers: Leading and Building Organizations of Integrity. New York: Routledge, 2017, 320 s. ISBN 978-1-138-19016-0. 
otázky, ktoré legislatíva nerieši, ale možno ich vnímat’ aj ako reakciu na očakávania verejnosti vyžadujúce dôveru, zodpovednost' a skladanie účtov. ${ }^{19}$ Podl’a odborníka na etiku verejnej správy Donalda C. Menzela je dôraz na normatívny rozmer etiky využívaný predovšetkým v demokratických spoločnostiach, ale aj v spoločnostiach, ktoré sa po autoritárskom režime snažia stat' viac demokratickými. ${ }^{20}$ Tento fakt úzko súvisí aj s normatívnost’ou profesijnej etiky, ktorá je často stotožňovaná práve so súborom pravidiel správania sa pre príslušníkov konkrétnej profesie. Z pohl’adu uplatnenia myšlienok etických teórií je etický kódex ukážkovým a tradičným výsledkom deontologickej etickej teórie. Morálny kredit je v kontexte deongologickej etickej koncepcie určený súladom s povinnost'ou, ktorá nie je založená na intuícii, svedomí alebo užitočnosti. ${ }^{21} \mathrm{Je}$ však potrebné zdôraznit', že pre deontológa je najdôležitejší mravný rozdiel medzi prípustným a neprípustným, čo ústi v definíciu povinného cez predstavu neprípustnosti určitého konania. ${ }^{22}$ Tento základ predmetnej etickej koncepcie je jej poznávacím znakom, ktorý ju odlišuje od ostatných najdiskutovanejších etických teórií súčasnosti.

Normatívny rozmer zohl'adňovania etického aspektu praxe možno na základe uvedeného považovat' za potrebnú súčast’ praxe verejnej správy v demokratických spoločnostiach. V tomto zmysle možno normy etického charakteru vnímat' vo vzt'ahu k platným a účinným právnym normám ako základný nástroj riadenia etického aspektu, ktorým možno regulovat' správanie sa, konanie a rozhodovanie zamestnancov podiel'ajúcich sa na každodennej činnosti verejnej správy.

\section{Normy etického charakteru $v$ podmienkach verejnej správy na Slovensku}

Reálny stav normatívneho rozmeru zohl'adňovania etického aspektu je v rámci jednotlivých subsystémov verejnej správy z hladiska kvantity a kvality spracovania etických kódexov na značne odlišnej úrovni. Najviac etických kódexov je prijímaných subjektami územnej samosprávy. V tomto zmysle sa plnohodnotne prejavuje podstata územnej samosprávy, ktorá spočíva v samorozhodovaní v rámci legálne vymedzenej pôsobnosti. ${ }^{23}$

19 GUERAS, Dean a Charles GAROFALO. Practical Ethics In Public Administration. Vienna: Management Concepts, 2011, 460 s. ISBN 978-1-56726-295-7.

20 MENZEL, Donald C. Ethics and Integrity in Public Service: Issues and Challenges. In: MENZEL, Donald C. a Jay D. WHITE (eds.). The State of Public Administration: Issues, Challenges, and Opportunities. New York: Routledge, 2015, s. 108-124. ISBN 978-0-7656-2504-5.

21 LAWTON, Alan, Julie RAYNER a Karin LASTHUIZEN. Ethics and Management in the Public Sector. Abingdon: Routledge, 2013, 208 s. ISBN 978-0-415-57760-1.

22 GLUCHMAN, Vasil. Deontologická etika. In: GLUCHMAN, Vasil a kol. Etické teórie súčasnosti: Etika II. Prešov: Grafotlač Prešov, 2010. s. 119-132. ISBN 978-80-970485-0-1.

23 ALMAN, Tomáš. Miestne referendum a zhromaždenie obyvatel’ov obce ako formy priamej demokracie. In: ŽOFČINOVÁ, Vladimíra (eds.). Formy uskutočňovania obecnej samosprávy. Košice: Univerzita Pavla Jozefa Šafárika v Košiciach, 2017, s. 81-90. ISBN 978-80-8152-543-8. 
Tento fakt výrazne korešponduje so silou samosprávy, ktorá dokáže zo všetkých subsystémov verejnej správy reagovat' najpromptnejšie na potreby verejnosti, pretože v konečnom dôsledku je vykonávaná na úrovni, ktorá je najbližšie občanovi.

Normy etického charakteru sú však pri porovnaní s normami právneho charakteru značným spôsobom odlišné vo viacerých rozmeroch. Predovšetkým je potrebné povedat', že v podmienkach Slovenskej republiky neexistuje žiadny rámcový dokument, ktorý by aspoň demonštratívne poukazoval na očakávané alebo želatel'né náležitosti etických kódexov. V rámci legislatívy sa vzhladom na právne účinky dôsledne sleduje platnost' a účinnost'. Informácia o platnosti a účinnosti by však rovnako mala byt' súčast'ou každej etickej normy. Avšak prax ukazuje, že nie každý etický kódex obsahuje tieto podstatné informácie. Súčasne možno poukázat' aj na samotný obsah etických kódexov, kde možno identifikovat' kódexy, ktoré sú štruktúrované do článkov, ale aj kódexy, ktoré sú spracované vo forme deklarácií. Často diskutovanou otázkou je aj forma vydania etického kódexu. V praxi sa totiž objavujú kódexy, ktoré majú formu smernice, nariadenia, smernice primátora, vnútorného predpisu alebo sú spracované ako súčast' pracovného poriadku. Tieto odlišnosti sa navyše obmieňajú aj pri porovnávaní etických noriem prijímaných v rámci štátnej správy a územnej samosprávy. Preto bude pozornost’ bezprostredne nasledujúcej časti textu upriamená na reálne existujúci stav.

\subsection{Reálny stav uplatňovania etických kódexov vo verejnej správe}

Existenciu snahy transformovat' do verejnej správy princípy, na základe ktorých sú želatel'ným spôsobom interpretované všetky d’alšie situácie, možno nepriamo identifikovat' aj v rámci legislatívy. Za kl'účový možno z pohl'adu štátnej správy považovat' zákon o štátnej službe, ktorý nadobudol účinnost' 1. júna 2017. Obsahuje totiž princípy, ktoré nie sú len vymenované, ale sú doplnené aj krátkym popisom. Možno hovorit' o kvalitatívnej zmene k lepšiemu, pretože v predchádzajúcom znení zákona č. 400/2009 Z. z. o štátnej službe a o zmene a doplnení niektorých zákonov zákonodarca považoval za postačujúce len spomenút', že štátna služba je budovaná na princípe profesionality, politickej neutrality, nestrannosti, efektivity, stability štátnozamestnaneckého pomeru a etiky.

Vychádzajúc z aktuálne platného zákona o štátnej službe možno hovorit’ o nasledovných princípoch, ktoré síce nemajú výlučne etický charakter, ale v určitých aspektoch disponujú potenciálom smerujúcim $\mathrm{k}$ využívaniu komplementárneho pôsobenia etického normatívneho systému. Ako prvý je zákonom uvedený princíp politickej neutrality, v súlade s ktorým je štátny zamestnanec povinný vykonávat’ štátnu službu s dôrazom na verejný záujem. Princíp zákonnosti pojednáva o vykonávaní štátnej služby v súlade s legislatívou a zabezpečením ochrany pred nezákonným konaním. Štátny zamestnanec by mal s dôrazom na princíp nestrannosti uprednostnit' verejný záujem pred osobným záujmom. S odvolaním sa na princíp profesionality koná odborne, svedomito a v súlade s Etickým kódexom štátneho zamestnanca, pričom verejná správa vytvára podmienky 
k rozvíjaniu uvedených kvalít. Ďalšie princípy sa vzt’ahujú skôr na vzt’ah služobný úrad a zamestnanec. Ide o princíp transparentného zamestnávania, kedy je potrebné zabezpečit' rovnaký prístup k informáciám pre všetkých uchádzačov a následne aj transparentné a rovnaké odmeňovanie. Súčasne je potrebné dodržat' povinnost' ochrany štátneho zamestnanca pred skončením pomeru z iných ako zákonne stanovených dôvodov, čím je do praxe uvedený princíp stability. Posledným uvedeným je princíp rovnakého zaobchádzania obsahujúci dôraz na rešpektovanie súkromia. Viacerými princípmi je navyše čiastočne reflektovaná požiadavka dôvernosti a nezneužívania informácií získaných v súvislosti s plnením pracovných povinností.

Uvedené princípy sa stotožňujú predovšetkým s reflexiou etických požiadaviek v zmysle predchádzania konfliktu záujmov, transparentnosti, neutrality a nestrannosti. Súčasne je však potrebné poznamenat', že absentuje dôraz na sledovanie etickej integrity, nezávislosti, lojality alebo osobnej zodpovednosti. V zásade však možno uchopenie princípov oproti predchádzajúcemu stavu hodnotit' kladne. Na druhej strane možno hovorit' aj o nevyužitom potenciáli. Súčasne je potrebné poznamenat', že zákon o štátnej službe odkazuje ako jediný na normu etického charakteru, ktorou je Etický kódex štátneho zamestnanca. Zároveň však možno identifikovat’ etické kódexy, ktoré sú prijímané jednotlivými orgánmi štátnej správy. Ide napríklad o ministerstvá, Finančnú správu Slovenskej republiky alebo Najvyšší kontrolný úrad Slovenskej republiky. Súčasne je na tomto mieste potrebné poznamenat', že vzhl'adom na počet orgánov štátnej správy možno považovat' analýzu všetkých etických kódexov za náročnú úlohu, ktorá svojou komplexnost'ou presahuje ambíciu predkladaného textu.

Paralelne je potrebné vnímat' zohl'adňovanie etiky v územnej samospráve, ktorá je integrálnou súčast'ou demokratickej spoločnosti. Činnost' zamestnancov obcí a miest nie je v kontexte predmetnej problematiky ucelene v koncepčnom význame regulovaná, čo je vzhl'adom na množstvo kompetencií a značný objem finančných prostriedkov, ktoré samosprávy spravujú zarážajúce. Subjekty územnej samosprávy však reflektujú potrebu regulácie etického aspektu ich činnosti a iniciatívne prijímajú etické kódexy zamestnancov. Územná samospráva je obdobne z hl’adiska etických noriem vel'mi t'ažko vyčerpávajúco opísatel'ná. Hlavným dôvodom je výrazná územná fragmentácia, výsledkom čoho je existencia značného počtu malých samospráv. Z celkového počtu obcí 2890 je viac ako 1150 takých, ktoré majú menej ako 500 obyvatel’ov, pričom viac ako 400 obcí nedisponuje počtom obyvatelov, ktorý by presahoval číslo $250 .{ }^{24}$ Pri takmer troch tisíckach územných samosprávnych celkov možno exaktne identifikovat' využívanie etických kódexov na úrovni miest a samosprávnych krajov. Normy etického charakteru sú uplatňované v 46 mestách, čo v percentuálnom vyjadrení predstavuje takmer

24 PALÚŠ, Igor. Teoreticko-právne východiská obecnej samosprávy (so zameraním na podmienky Slovenskej republiky. In: ŽOFČINOVÁ, Vladimíra (eds.). Formy uskutočnovania obecnej samospráyy. Košice: Univerzita Pavla Jozefa Šafárika v Košiciach, 2017, s. 14-27. ISBN 978-80-8152-543-8. 
$33 \%$ z celkového počtu 140 miest. To však neznamená, že obce etické kódexy prijaté nemajú, práve naopak. Na úrovni samosprávnych krajov má etický kódex zamestnancov prijatá presná polovica krajov. Prax však ukazuje, že etické kódexy nie sú prijímane len za účelom regulácie zamestnancov obecných a mestských úradov alebo úradov samosprávnych krajov. Identifikovat' možno aj kódexy spracované v rámci organizácii, ktoré sú zriad’ované subjektmi územnej samosprávy. Najčastejšie sa jedná o mestské podniky, organizácie v zriad’ovatel'skej pôsobnosti mesta alebo mestskú políciu.

Prijímanie noriem etického charakteru možno identifikovat’ aj v rámci záujmovej samosprávy a etické kódexy sú prijímané aj verejnoprávnymi inštitúciami. Napriek zúženiu skúmanej problematiky, na oblast’ štátnej správy a územnej samosprávy, je predsa len vhodné aspoň okrajovo venovat' priestor aj týmto súčastiam verejnej správy. Vzhl’adom na zverené úlohy súvisiace s dosahovaním verejného záujmu by bolo úplné vynechanie týchto subjektov krátkozraké a mylné. Podobne ani v rámci tejto skupiny subjektov nemožno hovorit' o existencii vzorového či odporúčacieho kódexu. V súvislosti s dosahovaním zverených úloh a v záujme zabezpečenia verejného záujmu je etickými kódexami profesijnej samosprávy regulované správanie sa členov profesijných inštitúcií. V tomto kontexte možno spomenút' normy etického charakteru prijaté napríklad v rámci Slovenskej komory znalcov, Notárskej komory Slovenskej republiky alebo Slovenskej lekárskej komory. V rámci Slovenskej komory audítorov a Slovenskej advokátskej komory však možno hovorit’ o určitom špecifickom prístupe. Etické kódexy síce tieto komory neprijali, ale deklarovali dodržiavanie normy, ktorá je prijatá na nadnárodnej úrovni. Súčasne majú normy etického charakteru prijaté aj subjekty, ktoré sú v teórii zarad'ované medzi špeciálnu samosprávu. Teória často vymedzuje školskú respektíve akademickú samosprávu. Normy etického charakteru za účelom regulácie správania sa zamestnancov a študentov majú prijaté viaceré univerzity, ako napríklad Univerzita Pavla Jozefa Šafárika v Košiciach, Univerzita Mateja Bela v Banskej Bystrici, Univerzita Komenského v Bratislave alebo Žilinská univerzita. Výnimkou nie je ani prijímanie kódexov v rámci stredných a základných škôl. V rámci verejnoprávnych inštitúcií možno obdobne identifikovat' snahu zohl'adňovat' etický aspekt ich činnosti. Poukázat' možno na etické kódexy, ktoré prijala Národná banka Slovenska, Sociálna poist'ovňa alebo Slovenská akadémia vied. Subjekty záujmovej samosprávy a verejnoprávne inštitúcie predstavujú pomerne nekoherentný celok. Charakter tejto skupiny organizácii je do výraznej miery reflektovaný v špecifickosti jednotlivých etických noriem, ale aj rozmanitosti adresátov, ktorým sú etické kódexy určené.

$\mathrm{Na}$ druhej strane je verejnú správu potrebné vnímat' aj v kontexte základnej zásady demokratickej verejnej moci a demokratického vládnutia, ktorou je del’ba moci. Verejná správa sa totiž realizuje ako prejav výkonnej moci v štáte. ${ }^{25}$ Práve z tohto dôvodu a na základe komplexnosti skúmanej problematiky možno za žiadúce považovat’ aspoň

25 ŠKULTÉTY, Peter. Verejná správa a správne právo. Bratislava: VEDA, 2008, 204 s. ISBN 978-80-224-1023-6. 
v podstatných súvislostiach spomenút' aj opodstatnenost' etického rozmeru činnosti, ktorá je reflektovaná v rámci zákonodarnej aj súdnej moci. Potrebné je však poznamenat', že postavenie, uplatňovanie a dodržiavanie noriem etického charakteru je v rámci týchto dvoch zložiek moci vo vzt’ahu k skúmanej problematike podstatne odlišné.

Zásady sudcovskej etiky ${ }^{26}$ sú kódexom, ktorý bol prijatý Súdnou radou Slovenskej republiky a jeho ustanovenia upravujú správanie sa sudcov. V kontexte sudcovskej etiky poukazuje predmetná etická norma na všeobecné zásady, ktorými sú zásada nezávislosti a nestrannosti, zásada bezúhonnosti, zásada spravodlivosti a transparentnosti, zásada zdvorilosti, diskrétnosti dôvernosti a tolerantnosti, ale aj zásada rovnakého zaobchádzania a kompetentnosti. Súčasne vyzdvihuje etická norma osobné kvality sudcu, ktorými sú najmä l'udskost', odvaha, serióznost', rozvážnost', pracovitost', rešpekt a schopnost' načúvat'. Zároveň sú v etickom rozmere formulované povinnosti pri výkone funkcie, voči profesii a povinnosti v občianskom živote. Všetky tieto všeobecné náležitosti sú konkretizované prostredníctvom pravidiel správania sa, ktoré tvoria podstatnú čast' predmetnej etickej normy.

Na druhej strane nemožno v rámci zákonodarnej moci hovorit’ o platnej a účinnej norme etického charakteru prijatej v rámci Národnej rady Slovenskej republiky (d’alej len NR SR), ktorej Ústava Slovenskej republiky túto moc zveruje. Iniciatíva z rokov 2015 a 2016 smerujúca k prijatiu takejto normy totiž zostala len v rovine návrhu. Samotný návrh Etického kódexu poslanca bol členený do článkov, ktoré sa venovali základným etickým princípom, konfliktu záujmov, darom a iným výhodám, deklarácií majetkových a finančných pomerov, transparentnosti pri výkone funkcie poslanca, zneužitiu funkcie poslanca, rešpektovaniu úloh zamestnancov kancelárie a postupu pri porušení samotnej normy. ${ }^{27}$ Napriek tomu možno v rámci legislatívy, konkrétne v zákone číslo 350/1996 Z.z. o rokovacom poriadku Národnej rady Slovenskej republiky, identifikovat' ustanovenia súvisiace s normou etického charakteru, ktorá bola v rámci návrhu zákona nazvaná ako Etický kódex poslanca. Predmetný zákon paradoxne napriek absencii samotnej normy stanovuje povinnost' poslancov dodržiavat' navrhovanú normu, ktorú môže NR SR prijat' uznesením.

Vzhl'adom na parciálnost' tejto problematiky vo vzt'ahu k nosnému ciel'u štúdie, možno čo do rozsahu považovat' priestor venovaný zohl'adňovaniu etiky v rámci zákonodarnej a súdnej moci za dostatočný. Napriek tomu možno v kontexte skúmanej problematiky venovat' patričnú pozornost' aspoň sankciám v prípade porušenia uvedených etických noriem.

26 Zásady sudcovskej etiky [online]. 2015 [cit. 20.11.2017]. Dostupné z: http://www.sudnarada.gov.sk/data/ files/ 680_zasady-sudcovskej-etiky.pdf

27 Náurh poslancov Národnej rady Slovenskej republiky Petra Pellegriniho, Miroslava Čžza a Jany Lašsákovej na vydanie zákona, k.torým sa meni a doplña zákon Národnej rady Slovenskej republiky c. 350/1996 Z. z. o rokovacom poriadku Národnej rady Slovenskej republiky v żneni neskoršich predpisov [online]. 2015 [cit. 20.11.2016]. Dostupné z: http://www.nrsr.sk/web/Dynamic/Download.aspx?DocID=418224 
Sankčný mechanizmus je v rámci zákona 350/1996 Z.z. o rokovacom poriadku Národnej rady Slovenskej republiky stanovený tak, že samotný poslanec podlieha disciplinárnej právomoci NR SR v prípade jeho porušenia, pričom návrh na začatie konania v Mandátovom a imunitnom výbore NR SR môže podat' orgán zákonodarného zboru alebo poslanec. Súčasne predmetný zákon paradoxne aj napriek absencii kódexu stanovuje sankciu v prípade jeho porušenia, ktorá môže byt' až do výšky $500 €$, pričom o tejto sankcii by mala rozhodovat' NR SR na základe odporúčania príslušného výboru.

V súvislosti s dodržiavaním Zásad sudcovskej etiky je potrebné poukázat' na samotné záruky, v rámci ktorých ako hlavný garanti vystupujú samotní sudcovia, orgány sudcovskej samosprávy a samotná Súdna rada Slovenskej republiky, ktorá predmetnú etickú normu upresňuje výkladom. Orgány sudcovskej samosprávy sú oprávnené v rámci disciplinárnej právomoci posudzovat', či je správanie sudcu v rozpore s normou etického charakteru. Samotný dokument sa pritom v tejto súvislosti opiera o normy právneho charakteru, ktorými sú zákon číslo 385/2000 o sudcoch a prísediacich a o zmene a doplnení niektorých zákonov a zákon číslo 757/2004 o súdoch a o zmene a doplnení niektorých zákonov.

Vychádzajúc z doposial' uvedeného možno vyslovit' presvedčenie, že normy etického charakteru sa v podmienkach verejnej správy na Slovensku odlišujú vo viacerých základných aspektoch. Vychádzajúc z odlišností týkajúcich sa formy a spôsobu prijatia, štruktúry etickej normy alebo okruhu adresátov je potrebné zohl'adnit' d'alší dôležitý faktor. Ide o samotné koncipovanie obsahu, ale aj práv a povinností vyplývajúcich z jednotlivých etických kódexov. Z tohto dôvodu bude tomuto rozmeru normatívneho aspektu etiky vo verejnej správe venovaný osobitný priestor v nasledujúcej podkapitole.

\subsection{Obsah a štruktúra etických kódexov vo verejnej správe}

Etické kódexy sú predovšetkým reflexiou slobodnej vôle jednotlivých organizácií verejnej správy zohl'adňovat' etický aspekt ich každodennej praxe. Z tohto dôvodu je obsah etických noriem determinovaný preferenciami jednotlivých organizácií, ale zároveň aj charakterom ich činnosti a samotným okruhom adresátov. S dôrazom na tieto faktory sa pokúsime v nasledujúcej časti textu poukázat' na odlišnosti, ktoré sa týkajú koncipovania etických požiadaviek v jednotlivých normách etického charakteru v štátnej správe a územnej samospráve.

\subsubsection{Normy etickébo charakteru v štátnej správe}

Štátna správa nie je v prijímaní noriem etického charakteru, príliš iniciatívna. V konečnom dôsledku je to však dané jej samotným charakterom. Na rozdiel od ostatných subsystémov je racionálnejšie a efektívnejšie regulovat' správanie sa štátnych zamestnancov univerzálnym kódexom. Najširší počet adresátov je vo verejnej správe na Slovensku regulovaný práve Etickým kódexom štátneho zamestnanca. Zákon o štátnej službe odkazuje na jeho dodržiavanie a súčasne upravuje, že vykonávacím predpisom ho vydáva Úrad 
vlády Slovenskej republiky. Na dodržiavanie kódexu odkazuje dokonca aj text sl'ubu, ktorý je spájaný s prevzatím služobnej zmluvy štátnym zamestnancom.

Predmetný Etický kódex štátneho zamestnanca ${ }^{28}$ možno považovat’ za zastaraný, ale pozitívom je, že niektoré jeho časti boli na vtedajšiu dobu spracované podrobne a vychádzajú z potreby obmedzit' problémy, ktoré pretrvali dodnes. Ide o konflikt záujmov, prijímanie darov, využívanie zdrojov alebo zneužitie úradného postavenia. Kódex upravuje viacero možných druhov konfliktu záujmov. Zároveň upravuje podrobne aj prijímanie darov a iných výhod, pričom obe spomínané oblasti sú koncipované tak, aby sa štátny zamestnanec zdržal konania a vyhýbal sa situáciám, ktoré by čo i len potencionálne ohrozili riadne plnenie štátno-zamestnaneckých povinností. Pozitívom je aj vyzdvihovanie dôležitosti transparentnosti štátnej služby, ktorá ani dnes nestratila na význame. Najrozsiahlejšia čast' normy je venovaná zneužitiu úradného postavenia, ktoré nemôže za žiadnych okolností nastat'. Podrobne sú upravené situácie týkajúce sa zneužitia úradného postavenia zo strany zamestnanca, ale aj nadriadeného. Kódex zároveň rámcovo upravuje aj oblasti, ktorými sú nakladanie s informáciami, ochrana majetku a oznamovanie neprípustnej činnosti. Na druhej strane je však potrebné konštatovat', že kódex ako celok nevyhnutne potrebuje revíziu. Používa napríklad pojem predstavený, ktorý v súčasnej legislatíve nemá oporu a je odkazom na staršie verzie zákona o štátnej službe. Text kódexu zároveň nekorešponduje s ambíciami reflektujúcimi aktuálne a všeobecne rozšírené problémy. V tomto zmysle nie je venovaná patričná pozornost' etickej integrite a zodpovednost' je vnímaná výlučne len ako koncept vzt'ahujúci sa na plnenie pracovných povinností. Z hladiska koncepčnosti by však pri určitých úpravách mohol byt' východiskom pre spracovanie etických kódexov v jednotlivých organizáciách verejnej správy.

$\mathrm{V}$ rámci štátnej správy však možno identifikovat’ aj iniciatívy smerujúce k vytvoreniu podrobnejších a špecifickejších etických noriem. Dokument Akčný plán na posilnenie Slovenskej republiky ako právneho štátu upravuje povinnost' prijímat' a uplatňovat' rezortné etické kódexy štátnych zamestnancov. ${ }^{29}$ Doposial' boli takéto kódexy prijaté napríklad Ministerstvom vnútra alebo Ministerstvom práce sociálnych vecí a rodiny. Súčasne možno poukázat’ aj na etický kódex prijatý v rámci Finančnej správy alebo Najvyššieho kontrolného úradu.

Etický kódex štátneho zamestnanca a zamestnanca pri výkone práce vo verejnom záujme Ministerstva práce, sociálnych vecí a rodiny Slovenskej republiky ${ }^{30}$ má z hl’adiska

28 Etický kódex štátneho zamestnanca [online]. 2018 [cit. 10.1.2018]. Dostupné z: http://www.minv. sk/?eticky-kodex-statneho-zamestnanca

29 Akéný plán na posilnenie Slovenskej republiky ako právneho štátu [online]. 2015 [cit. 15. 11.2017]. Dostupné z: http://www.rokovania.sk/File.aspx/ViewDocumentHtml/ Mater-Dokum-189280?prefixFile=m_

30 Etický kódex śtátneho zamestnanca a zamestnanca pri výkone práce vo verejnom záujme Ministerstva práce, sociálnych vecí a rodiny Slovenskej republiky [online]. 2013 [cit. 15. 11.2017]. Dostupné z: https://www.employment. gov.sk/files/ministerstvo/eticky-kodex.pdf 
štruktúry určité špecifické znaky. V rámci základných zásad rozpracováva v pätnástich odsekoch viaceré oblasti, ktoré sú spravidla spracované ako osobitné časti etickej normy. Okrem základných zásad rozpracováva táto čast’ napríklad aj prijímanie darov, nakladanie s majetkom alebo vzt’ahy na pracovisku. Takýto postup pri spracovaní kódexu môže viest' k prípadnej nedôslednosti a neadekvátnej úprave konkrétnych práv a povinností. Napriek tomu, predovšetkým problematika darov je spracovaná podrobne. Jedinou oblast'ou, ktorá je v predmetnom kódexe spracovaná ako osobitná čast' je konflikt záujmov. Súčasne je potrebné poznamenat', že táto čast’ je spracovaná kvalitne a v kontexte aktuálnych trendov riešenia tejto podstatnej otázky etiky vo verejnej správe. Etický kódex štátnych zamestnancov vykonávajúcich štátnu službu v služobnom úrade Ministerstva vnútra Slovenskej republiky ${ }^{31}$ je orientovaný na výsostne zachovávanie profesionality pri činnosti jednotlivcov, ako napríklad vo vzt'ahu k dodržiavaniu mlčanlivosti, politickej neutrálnosti a nestrannosti, rešpektovaní iných zamestnancov, v súvislosti s konfliktom záujmov alebo vystupovaní či nezneužívaní služobného postavenia. Zároveň vo svojej zvyšnej časti prostredníctvom osobitných článkov podrobne stanovuje práva a povinnosti vo vzt’ahu k zneužitiu služobného postavenia a konfliktu záujmov.

Etické kódexy však v rámci štátnej správy nemajú spracované len ministerstvá. Špecificky je spracovaný aj Etický kódex finančnej správy ${ }^{32}$, ktorý nemá podobu článkov a ustanovení, ale je formulovaný v zmysle deklarovania kvalít zo strany zamestnanca. Kladie dôraz na profesionálny prístup, preferuje l'udský prístup, ochranu nadobudnutých informácií, poskytovanie podpory pre klientov, vzájomnú dôveru a snahu o transparentné dodržiavanie zákonom stanovených povinností. Etický kódex zamestnanca Najvyššieho kontrolného úradu Slovenskej republiky ${ }^{33}$ obsahuje v podstate tradičné náležitosti etickej normy. Po úvodných ustanoveniach koncentruje svoju pozornost’ na základné pravidlá správania sa zamestnancov, konflikt záujmov a prijímanie darov. V článku nazvanom Osobitné ustanovenia pre zamestnancov vykonávajúcich kontrolu sa plne prejavuje špecifickost' samotnej organizácie, pričom tento článok tvorí podstatnú čast' kódexu. Tento fakt možno považovat' za logické vyústenie kompetencií, ktoré sú úradu zverené priamo Ústavou Slovenskej republiky.

Štátnu správu je teda možné z hl'adiska normatívneho rozmeru zohl’adňovania etiky hodnotit' rozporne. Kým na jednej strane je relatívne správnym krokom existencia kódexu vzt'ahujúceho sa na všetkých štátnych zamestnancov, na druhej strane nie je dostatočne využitý jeho potenciál. Súčasne nie je dostatočne využívaná jeho d’alšia konkretizácia

31 Nariadenie vedúcej služobného úradu Ministerstva vnútra Slovenskej republiky č. 15/2012 o etickom kódexe štátnych zamestnancov vykonávajúcich štátnu službu v služobnom úrade Ministerstva vnútra Slovenskej republiky.

32 Etický kódex finančnej spráyy [online]. 2015 [cit. 15.11.2017]. Dostupné z: https://www.financnasprava. sk/_img/pfsedit/Dokumenty_PFS/Financna_sprava/Rozne/2015.12.30_et_kodex.pdf

33 Etický kódex zamestnanca Najyyššeho kontrolného úradu Slovenskej republiky [online]. 2015 [cit. 15.11.2017]. Dostupné z: https://www.nku.gov.sk/eticky-kodex-zamestnanca-nku-sr 
a prispôsobenie. Napriek tomu možno identifikovat' d’alšie samostatné iniciatívy, ktoré sú však v podmienkach Slovenska skôr výnimkou.

\subsubsection{Normy etického charakteru v územnej samospráve}

Prijímanie kódexov vzt'ahujúcich sa na zamestnancov miest a obcí nebolo regulované žiadnou národnou autoritou, a preto sú ich ustanovenia formulované rôzne, ale napriek tomu možno povedat', že vel'mi podobne. Určitým negatívom identifikovatel'ným v etických kódexoch územnej samosprávy je fakt, že niektoré ustanovenia sú dokonca až doslovne totožné. Rovnaký jav je pozorovatel'ný pri kódexoch samosprávnych krajov, kde možno hovorit' o ešte výraznejšom konceptuálnom prekryve. Rámcovo možno normy etického charakteru v územnej samospráve na Slovensku z obsahového hl’adiska charakterizovat' nasledovným spôsobom.

Východiskom kódexov územnej samosprávy sú etické princípy, hodnoty alebo zásady. Určujúcim princípom je spravidla zákonnost', ktorá je vnímaná aj ako súčast’ sledovania verejného záujmu. Pozornost' je však prioritne orientovaná na plnenie legislatívne zakotvených povinností, interných noriem a etických kódexov. V niektorých prípadoch však býva sledovanie verejného záujmu formulované prostredníctvom osobitného ustanovenia. Nadväzne je často formulovaná povinnost' predchádzat' konfliktu záujmov. Opodstatnene kódexy obsahujú princípy, ktorými sú nestrannost', nezávislost' a objektívnost'. Etickými kódexmi sú d’alej deklarované aj princípy, ako napríklad transparentnost' a zodpovednost', aj ked' v oboch prípadoch možno hovorit' len o minimalistických etických požiadavkách. Normy etického charakteru často v rámci úvodnej časti poukazujú aj na profesijné etické kvality zamestnancov. Najčastejšie vyžadujú súlad správania sa, konania a rozhodovania s cnost'ami, ako napríklad čestnost', zdvorilost', svedomitost', dôvernost', odbornost', mlčanlivost' alebo tolerantnost'.

Jednou z často sa opakujúcich súčastí je konflikt záujmov. Vo sfére správy veci verejných by táto situácia nemala nastat', ale ak dôjde $\mathrm{k}$ jej vzniku, mala by byt' vyriešená v prospech verejného záujmu. Etické kódexy územnej samosprávy vnímajú túto situáciu prevažne vo význame akejkol’vek výhody pre zamestnanca, jeho rodinu a blízke osoby. Už menej často sú do predmetného okruhu osôb zaradené aj iné fyzické a právnické osoby, s ktorými zamestnanec bol alebo stále je v priatel’skom, obchodnom alebo politickom vzt'ahu. Kódexy často stanovujú povinnost' oznamovat' potenciálny alebo skutočný konflikt záujmov, ako aj povinnost' nepripustit' vznik takejto situácie. Súčasne je stanovovaná povinnost' nezúčastňovat' sa aktivít, ktoré by mohli ohrozit' riadne plnenie pracovných povinností. Prípadný konflikt by mal byt' oznámený stanoveným spôsobom. Kladne možno vnímat' upriamenie pozornosti na viaceré rozmery konfliktu záujmov, vd'aka čomu sa táto problematická oblast' stáva jednou z najviac prepracovaných.

Bežná l’udská činnost', ktorá však v rámci verejnej správy musí byt' v zmysle zachovania nestrannosti, nezávislosti a objektívnosti regulovaná, je prijímanie darov a iných výhod. 
Viacero kódexov stanovuje povinnost' odmietnut' dar a iné výhody, pričom o tejto akcii by mal byt' informovaný nadriadený alebo inštancia etického charakteru. Ojedinelým riešením, avšak značne kvalitatívne lepším, je stanovenie výnimiek v podobe určenia maximálnej sumy, do ktorej je možné dar prijat’. Vhodným nástrojom je aj existencia registra darov, do ktorého sa registrujú bud' všetky dary alebo len dary hodnotovo prekračujúce stanovenú sumu. Správne však možno identifikovat' bezpodmienečnú povinnost' neprijímat' dary vplývajúce na konanie a rozhodovanie osoby, ktorá dar alebo inú výhodu prijala. Zároveň je z objektívnych dôvodov potrebné pozitívne hodnotit' aj spomenuté výnimky. Napriek snahe regulovat' konflikt záujmov a prijímanie darov, zohladňovanie etického aspektu nemožno obmedzovat' len na tieto oblasti. Ďalšou otázkou je ašpirácia predchádzat' v čo najväčšej možnej miere situáciám, ktoré možno súhrnne nazvat’ ako zneužitie úradného postavenia. Najvšeobecnejšou rovinou zabraňujúcou tejto neželatel’nej forme správania sa je povinnost' nezneužívat' postavenie zamestnanca a výhody z neho vyplývajúce. Časté je aj nezneužívanie úradného postavenia v zmysle vzt'ahov nadriadenosti a podriadenosti, výhod vyplývajúcich z postavenia počas a po skončení pracovného pomeru, ako aj zneužívanie úradného postavenia v kontexte práce s informáciami. Bez ohladu na šírku chápania zneužívania úradného postavenia, ide o situáciu, ktorá je z pohl'adu verejnej správy ako garanta napíňania verejného záujmu neprípustná. Z tohto hl'adiska možno kladne hodnotit' fakt, že väčšina kódexov sa aspoň čiastočne, ale spravidla podrobne venuje tomuto neželatel'nému javu.

Nástrojov ako zabránit’ zneužívaniu právomocí je viacero. Možno k nim zaradit’ aj oznamovanie neprípustnej činnosti, ktorá je v rozpore s legislatívou, internými predpismi a ustanoveniami etického kódexu. Vo všeobecnosti možno povedat', že oznamovaný by mal byt' konflikt záujmov, príkaz súvisiaci s porušením povinností, nesprávne využívanie zvereného majetku a verejných zdrojov alebo ponúknutie daru či inej výhody. Základnú povinnost' oznamovat' nežiadúce správanie sa a konanie formulujú etické kódexy vždy voči priamemu nadriadenému alebo zriadenému etickému orgánu. S aplikáciou na Slovensko a reflektujúc aktuálne trendy je potrebné poznamenat', že v tejto súvislosti je nevyhnutné zabezpečit' oznamovatel'ovi adekvátnu ochranu, ktorá však vo väčšine noriem absentuje.

Normatívna zložka etiky spočívajúca vo formulovaní súboru etických požiadaviek priam vyžaduje dodržiavanie stanovených požiadaviek, pretože v opačnom prípade by mala nasledovat' sankcia. Práve preto je nevyhnutné, aby kódexy obsahovali čast' zameranú na jednoznačné zadefinovanie sankčného mechanizmu. Normy etického charakteru v územnej samospráve, ktoré obsahujú zmienku o sankčnom mechanizme, stotožňujú porušenie etického kódexu s porušením pracovnej disciplíny. $\mathrm{V}$ tomto zmysle by porušenie malo byt' riešené v zmysle platných právnych predpisov. Úprava sankčného mechanizmu je skôr výnimkou a podobne je tomu aj pri úprave samotného procesu rozhodovania o uložení sankcie. 
Normy etického charakteru územnej samosprávy sa venujú aj iným oblastiam, ako napríklad vzt’ahy medzi zamestnancami, majetkové priznania, verejné obstarávanie, ochrana zvereného majetku alebo nakladanie s informáciami. Tieto oblasti sú však samostatne spracované len výnimočne. Rovnako je výnimkou spracovanie d’alšieho dokumentu etického charakteru. Napriek tomu majú niektoré mestá spracované smernice pre etiku, v rámci ktorých podrobnejšie rozpracovávajú prijímanie darov, oznamovaciu povinnost', sankčný mechanizmus alebo činnost’ špecializovaných organizačných súčastí.

Zámerom tejto kapitoly nebolo vyčerpávajúcim spôsobom popísat' obsah jednotlivých platných a účinných etických kódexov vo verejnej správe na Slovensku. Práve naopak, z obsahového hl’adiska sa táto čast' textu v záujme následného formulovania odporúčaní snažila skôr o demonštratívne vyzdvihnutie riešení jednotlivých situácií, ktoré sú v zohl'adňovaní etického aspektu praxe dôležité. Práve preto je potrebné, aby im bola v rámci noriem etického charakteru venovaná patričná pozornost’. Okrem koncipovania jednotlivých práv a povinností poskytla táto čast' textu pohl'ad na rôzne formy, podoby a prístupy k využívaniu etických kódexov vo verejnej správe na Slovensku.

\section{Možnosti zlepšenia aktuálneho stavu uplatňovania noriem etického charakteru ako komplementárneho regulátora správania sa zamestnancov vo verejnej správe}

Na základe myšlienok, ktoré sú obsiahnuté v jednotlivých kapitolách možno znova zdôraznit' opodstatnenost' prijímania etických kódexov pre zamestnancov. Predovšetkým je potrebné mat' na zreteli fakt, že správanie sa, konanie a rozhodovanie zamestnancov vo verejnej správe je prioritne regulované legislatívou. Etické normy však disponujú potenciálom komplementárneho regulátora. V súvislosti so skúmanou problematikou možno len súhlasit's názorom M. Adamcovej, ktorá poukazuje na fakt, že pre realizáciu výrazných štrukturálnych zmien je potrebné prostredie, v ktorom je samozrejmost'ou dodržiavanie zákonov a etických pravidiel. ${ }^{34}$

V prvom rade je potrebné poukázat' na fakt, že na Slovensku neexistuje všeobecný etický kódex alebo dokument odporúčacieho charakteru, ktorý stanovil aspoň minimálne etické požiadavky na správanie sa, konanie a rozhodovanie zamestnancov vo verejnej správe. Výhodou etického kódexu, ktorý by sa vzt’ahoval na všetky organizácie verejnej správy, by bola vysoká miera zjednotenia etických požiadaviek na činnost' zamestnancov. Ak by však takáto iniciatíva mala byt' úspešná a rešpektovaná, malo by íst' skôr o dokument typu „ten commandments“, ktorý by bol všeobecný a vyžadoval by konkretizáciu a prispôsobenie. Dokument tohto typu je podl'a A. Lawtona charakteristický

34 ADAMCOVÁ, Mária. Európska únia a aktuálne zmeny vo verejnej správe Slovenskej republiky. In: ÖLLÖS, Lászó, Dávid HAMPL a kol. Deset let v Európské Unii: Stav, quušsenosti, perspektivy. Kolín: Nezávisle centrum pro studium politiky na Academia Rerum Civilium, Vysoká škola politických a společenských věd, 2014, s. 90-96. ISBN 978-80-86879-43-7. 
tým, že svojim krátkym a jasným obsahom formuluje len základné princípy správania sa, konania a rozhodovania. ${ }^{35}$ Súčasne je však potrebné povedat', že takto koncipovaný dokument by výrazne napomohol prípadnej transformácií etických požiadaviek do platnej a účinnej legislatívy.

V súčasnosti len t'ažko možno hovorit' o existencii spoločných minimálnych etických požiadavkách vo verejnej správe na Slovensku. Prijímanie etických kódexov je totiž nekoordinované a forma, štruktúra a obsah jednotlivých kódexov sa niekedy až príliš odlišuje. Napriek tomu tento stav nemožno hodnotit' až príliš negatívne. Pozitívne je potrebné vnímat' snahu organizácií verejnej správy zohl'adňovat' etické dopady ich každodennej činnosti. Napriek tomu možno v súčasnej situácii, charakteristickej absenciou koncepčného alebo odporúčacieho dokumentu, vidiet' určité obmedzenie d’alšieho rozvoja skúmanej problematiky. V prvom rade je potrebné poukázat' na jeden dôležitý fakt. Etické kódexy sú živé dokumenty a v záujme nevyhnutnej reflexie aktuálnych etických výziev a nových poznatkov vyžadujú periodické prepracovanie. ${ }^{36} \mathrm{~V}$ tomto zmysle by koncepčný dokument odporúčacieho charakteru pomohol zlepšit’ aktuálnu prax predovšetkým v nasledujúcich dvoch rovinách. Pre subjekty verejnej správy, ktoré majú účinnú normu etického charakteru by obdobný dokument mohol predstavovat' podklad a ideál pre prípadnú revíziu ich kódexu. Na druhej strane pre subjekty, ktoré zatial' neregulujú správanie sa zamestnancov etickou normou, môže predstavovat' dokument odporúčacieho charakteru motiváciu prijat' etický kódex. Charakter štátnej služby priam vyžaduje existenciu etického kódexu, ktorý by bol adresne uplatnitel’ný v rámci celého územia štátu. Táto ambícia je čiastočne naplnená existenciou súčasného Etického kódexu štátneho zamestnanca. Vychádzajúc z uvedeného sa však možno domnievat', že kým v rámci štátnej správy možno hovorit' o reálne existujúcom národnom etickom kódexe, v podmienkach územnej samosprávy, vzhl’adom na jej samosprávny charakter o záväznej koncepcii prijatej mimo obcí, miest a samosprávnych krajov, možno momentálne, ale aj v blízkej budúcnosti len vel'mi t’ažko uvažovat'. Samozrejme je nevyhnutné dodat', že kým Etický kódex štátneho zamestnanca vzhl’adom na rok jeho vydania potrebuje revíziu. Kódexy vzt'ahujúce sa na zamestnancov územných samospráv možno považovat' za aktuálnejšie, pretože v určitých ohl’adoch reflektujú globálne trendy v zohl’adňovaní etického aspektu praxe verejnej správy.

Pozitíva sofistikovanejšieho uplatňovania noriem etického charakteru vo verejnej správe možno vnímat' vo viacerých rozmeroch. Najdôležitejšie pozitívum možno vidiet' v samotnej podstate skúmanej problematiky a teda v komplementárnom pôsobení popri

35 LAWTON, Alan. Developing and Implementing Codes of Ethics. In: Viešoji politika ir Administrativimas, Vilnius: Mykolo Romeiro Universitas, 2004, roč. 3, č. 7, s. 94-101.

36 REAMER, Frederic G. Ethical Competence in Social Work. In: COOPER, Terry L. a Donald C. MENZEL. Achieving Ethical Competence for Public Service Leadership. New York: Routledge, 2015, p. 163-188. ISBN 978-0-7656-3245-6. 
platnej a účinnej legislatíve. Analyzované etické normy formulujú požiadavky etického charakteru, ktoré právne normy neriešia v dostatočnej miere alebo ich neriešia vôbec. Napriek tomu ide o situácie, ktoré sa pri výkone správy veci verejných bežne vyskytujú. Predovšetkým ide o konflikt záujmov a prijímanie darov a iných výhod.

Konflikt záujmov je vo vzt’ahu k zamestnancom územnej samosprávy a štátnym zamestnancom spracovaný v relevantných právnych predpisoch. Zákon o štátnej službe sa konfliktu záujmov venuje len rámcovo. V rámci povinností a obmedzení štátneho zamestnanca formuluje v $\int 111$ ods. 1 písm. d) povinnost' zdržat' sa konania, ktoré by mohlo viest' ku konfliktu záujmu služobného úradu s osobnými záujmami, najmä povinnost' nezneužívat' informácie získané $\mathrm{v}$ súvislosti s vykonávaním štátnej služby na vlastný prospech alebo v prospech iného. Súčasne v \111 ods. písm. c) stanovuje povinnost' oznámit' bez zbytočného odkladu akýkol’vek skutočný alebo možný konflikt záujmov. Konflikt záujmov je zároveň spomínaný aj v rámci princípov politickej neutrality a nestrannosti. Na druhej strane zákon o výkone prác vo verejnom záujme v kontexte konfliktu záujmov používa pojem rozpor záujmov. Povinnost'ou zamestnanca je podl’a \ 8 predmetného zákona zdržat' sa konania, ktoré by k rozporu záujmov mohlo viest'. Samotný rozpor záujmov zákon o výkone prác vo verejnom záujme charakterizuje ako skutočnost', kedy zamestnanec uprednostní osobný záujem pred verejným záujmom.

Etické normy sa venujú konfliktu záujmov vel’mi podrobne. Stanovujú nie len povinnost' smerujúcu k zdržaniu sa konania, ktoré by mohlo znamenat' konflikt záujmov, ale jednotlivé ustanovenia poukazujú aj na d'alšie aspekty tohto neželatel’ného javu. Často stanovovaná povinnost' sa týka napríklad ašpirácie vyhnút' sa účasti na činnosti, ktorá sa nezlučuje s riadnym výkonom pracovných povinností. Zároveň možno identifikovat' aj formulácie, kedy by zamestnanec nemal byt' účastný situácie alebo činnosti, ktorá by mohla narušit' dôveru verejnosti v zamestnancov alebo samotný úrad. Vel'mi často je stanovená nie len povinnost' oznámit' potenciálny alebo reálny konflikt, ale aj možnost' poradit' sa $\mathrm{v}$ tejto súvislosti s nadriadeným alebo etickým orgánom. Vo všeobecnosti možno za konflikt záujmov považovat' situáciu, kedy sám zamestnanec, jeho rodina a blízke osoby získajú akúkol'vek výhodu. Súčasne sem niektoré kódexy vel'mi správne zarad'ujú aj iné fyzické a právnické osoby, s ktorými zamestnanec bol alebo stále je v priatel'skom, obchodnom alebo politickom vzt'ahu. V tejto súvislosti možno poznamenat', že takto rozšírený okruh osôb spadajúci pod konflikt záujmov spĺña aj tie najprísnejšie kritériá, ktoré sú spravidla súčast’ou kvalitne spracovaných etických kódexov.

Súhrnne je však potrebné považovat’ predchádzanie a riešenie konfliktu záujmov je v 21. storočí neoddelitel’nú súčast'ou správy veci verejných. ${ }^{37}$ Opodstatnenost' regulácie konfliktu záujmov je potvrdená aj v rámci eticky významných dokumentov existujúcich

37 PETERS, Anne. Conflict of Interest as a Cross-cutting Problem of Governance. In: PETERS, Anne a Lukas HANDSCHIN (eds.). Conflict of Interest in Global, Public and Corporate Governance. Cambridge: Cambridge University Press, 2012, s. 3-38. ISBN 978-1-107-02932-3. 
na nadnárodnej úrovni. Štandardy správania sa pre medzinárodnú občiansku službu, obsahujú v kontexte konfliktu záujmov usmernenia, podl’a ktorých by zamestnanec mal manažovat' svoje súkromné záujmy tak, aby konflikt nenastal, ale ak nemu dôjde, mal by byt' vyriešený v prospech záujmov organizácie. ${ }^{38}$ Konflikt záujmov je skutočne širokou oblast'ou etiky vo verejnej správe a možno ho popisovat' vo viacerých súvislostiach. Môže sa týkat' vykonávania iných zamestnaní, politických aktivít, zverejňovania finančných údajov alebo obmedzovania činností po skončení pracovného pomeru, ale aj prijímania darov. ${ }^{39}$

Prijímanie darov je d’alšou oblast'ou, ktorá je takisto ako konflikt záujmov upravená aj legislatívou. Zákon o štátnej službe sa prijímaniu darov a iných výhod venuje v \ 112 ods. 1 písm. b), v ktorom stanovuje povinnost' zamestnanca neprijímat' dary alebo iné výhody $\mathrm{v}$ súvislosti s vykonávaním štátnej služby, pričom výnimku tvoria dary a iné výhody, ktoré sú poskytované služobným úradom a dary poskytované pri oficiálnych rokovaniach alebo stretnutiach. Súčasne by štátny zamestnanec v súlade s \ 112 ods. 1 písm. c) nemal požadovat' dary alebo iné výhody alebo navádzat' iného na poskytovanie darov alebo iných výhod v súvislosti s vykonávaním štátnej služby. Zákon o výkone prác vo verejnom záujme v $\int 8$ odsek 2 písm. c) stanovuje, že zamestnanec nesmie požadovat' alebo prijímat' dary alebo iné výhody alebo navádzat' iného na poskytovanie darov alebo iných výhod v súvislosti a pri výkone práce vo verejnom záujme. To však neplatí, ak ide o dary alebo iné výhody poskytované obvykle pri výkone práce vo verejnom záujme, na základe zákona alebo zamestnávatel’om.

Ustanovenia noriem etického charakteru upravujú prijímanie darov a iných výhod spravidla v obdobnom duchu, ale $\mathrm{v}$ niektorých prípadoch možno identifikovat' jasnejšie a dôslednejšie upravenie práv a povinností zamestnancov. Stanovujú spravidla povinnost' zamestnancov nepripustit' vznik situácie, kedy by boli zaviazaní oplatit' im preukázanú službu alebo poskytnutú výhodu, pričom by to ovplyvnilo ich nestrannost', nezávislost’ alebo profesionálnost' v rozhodovaní alebo konaní. Etické kódexy zároveň obsahujú ustanovenia smerujúce $\mathrm{k}$ väčšej transparentnosti celej tejto problematickej oblasti, ktorá musí byt’ v rámci verejnej správy bezpodmienečne jasne upravená. Zamestnancom je v rámci niektorých kódexov ukladaná povinnost' oznámit' už len samotný návrh na poskytnutie daru alebo inej výhody. Táto povinnost' je formulovaná spravidla voči priamemu nadriadenému alebo zriadenému etickému orgánu. Ďalším nástrojom, ktorým je možné urobit’ prijímanie darov viac transparentným je vedenie registra darov, ktorý je vedený v niektorých mestách. Zároveň je možné v menej ako polovici etických kódexov miest identifikovat' aj výnimky súvisiace s prijímaním darov. Ide predovšetkým

38 Standards of Conduct for the International Civil Service [online]. 2013 [cit. 7. 11. 2016]. Dostupné z: http://icsc. un.org/resources/pdfs/general/standardsE.pdf

39 Putting Ethics to Work - A Guide for UN Staff [online]. 2012 [cit. 7.11. 2016]. Dostupné z: http://www. un.org/en/ethics/pdf/putting_ethics_to_work_en.pdf 
o výnimky, ktorými sú ocenenia za zásluhy, mimoriadne udalosti, bežné a obvyklé dary, ale aj stanovenie maximálnej hodnoty daru.

Uvedené práva a povinnosti, ktorými je regulovaná oblast' prijímania darov sú v jednotlivých normách koncentrované v odlišnej kvalite. Častejším javom je skôr rámcová úprava tejto oblasti. Prijímanie darov je ukážkovo upravené v Odporúčaní Rady OECD na zlepšenie etického správania sa vo verejnej službe. Tento dokument upravuje prijímanie darov, pri ktorých by sa ešte len mohlo zdat', že majú vplyv na výkon pracovných povinností alebo sú odmenou za vykonanú prácu. Modelový kódex navyše podrobne popisuje aká by mala byt' reakcia na tieto neprimerané ponuky. Dary a iné výhody by mali byt' odmietnuté a osoba, ktorá túto ponuku uskutočnila by mala byt' identifikovaná. Ak však nie je možné vyhnút' sa prijatiu, je potrebné darovanú vec uschovat' a čo najmenej ju používat'. V prípade, že to situácia umožňuje, verejný činitel' by mal získat' svedkov a vyhotovit' písomný záznam. Samozrejme takúto situáciu je potrebné nahlásit' nadriadenému a príslušným orgánom. ${ }^{40}$ Zákaz prijímania darov a iných benefitov zamestnancami verejnej správy je za účelom zachovania vysokých profesijných štandardov súčast’ou každého dobrého etického kódexu. ${ }^{41}$ Nevylučuje to však prípadné stanovenie výnimiek, čo je však už na zvážení každej organizácie verejnej správy. Oprávnenost' výnimiek v súvislosti s prijímaním výhod možno vnímat' vo viacerých rozmeroch. Ide o potreby zohladnenia situácií, kedy je odmietnutie daru nevhodné, spôsobilo by to nepríjemnosti alebo je to dokonca nemožné.

Etické kódexy d’alej podrobne upravujú d’alšie povinnosti, ktoré súvisia so zneužitím úradného postavenia. Právne predpisy riešia tento aspekt skúmanej problematiky len vo všeobecnej rovine. Normy etického charakteru však poukazujú na neprípustnost' zneužívania právomoci vo viacerých formách, ako napríklad získanie akéhokol’vek prospechu alebo výhody, neprivlastnenie si zvereného majetku alebo zdrojov, ich neoprávnene využitie v prospech inej osoby, nezneužívanie informácií alebo zachovávanie mlčanlivosti. Dôležitou súčast'ou kódexov, ktorá je legislatívne tak isto riešená spravidla len rámcovo, je oznamovacia povinnost'. Etické kódexy spravidla ukladajú povinnost' oznamovat' porušenia povinností, ktoré sami stanovujú. Dostávame sa teda k d’alšej dôležitej oblasti, ktorou je otázka sankcionovatel'nosti porušení práv a povinností uložených normami etického charakteru. Etický kódex štátneho zamestnanca v jeho aktuálnej podobe v podstate nie je prepojený na možnost' sankcionovat' jeho nedodržanie ani v samotnom texte kódexu, ani v zákone o štátnej službe. Sankcie vyplývajúce z porušenia etických kódexov sú v rámci niektorých samospráv spojené s disciplinárnym

40 Recommendation of the OECD Council on Improving Ethical Conduct in the Public Service [online]. 1998 [cit. 8.11.2016]. Dostupné z: https://www.oecd. org/gov/ethics/Principles-on-Improving-Ethical-Conduct-in-the-Public-Service.pdf

41 JOHNSON, David. Thinking Government: Public Administration and Politics in Canada. Toronto: University of Toronto Press. 2016, 528 s. ISBN 978-1-4426-3521-0. 
postihom v súlade s legislatívou. Súčasne však možno identifikovat' aj normy etického charakteru, ktoré neobsahujú prepojenie na žiadnu sankciu za prípadné nedodržanie obsiahnutých ustanovení.

Na základe uvedeného možno objektívne hovorit' o prieniku predmetných normatívnych systémov. Etický rozmer fungovania dnešnej spoločnosti a verejnej správy je právnym normatívnym systémom vytláčaný do úzadia. Často krát je kritériom správnosti súlad s legislatívou, ktorá však nemusí vždy zaručit’ aj súlad s eticky vymedzeným očakávaním. Na druhej strane je však potrebné zdôraznit', že ani správanie sa v súlade s etickou normou nemusí znamenat’ jej výlučne správnu aplikáciu. Ako každá norma vytvorená človekom totiž nemôže regulovat' všetky eventuálne variácie situácií, v ktorých sa môže zamestnanec ocitnút'. Z tohto dôvodu je teda zohl'adnenie správnosti alebo nesprávnosti správania sa, konania a rozhodovania na samotnom zamestnancovi. S odvolaním sa na vyššie spomenuté myšlienky je však potrebné aj v praktických súvislostiach zdôraznit' vzájomný komplementárny vzt'ah týchto dvoch normatívnych systémov. V praxi by teda nemalo dochádzat' k polemikám, či dochádza k nemožnosti postihnút' správanie regulované jedným normatívnym systémom druhým. Mal by prevládnut' pohl'ad nevyhnutnosti reálneho sankcionovania neprípustného konania, ktorý je podložený rozporom s požiadavkami. Práve v tomto zmysle je možné etickým normatívnym systémom stanovit’ požiadavky, ktoré právnemu nie sú vlastné a naopak, pričom rovnako je to aj v prípade uloženia sankcie.

Prihliadnuc na existujúce globálne trendy v oblasti implementácie etiky možno hovorit' o kreovaní špecializovaných etických inštancií s celoštátnou pôsobnost’ou. V prípade Slovenska na celoštátnej úrovni neexistuje orgán, inštitúcia či výbor, ktorého úlohou by bolo koncepčne rozpracovávat' a pravidelne revidovat' dokumenty týkajúce sa etického aspektu praxe verejnej správy. Je na dlhú odbornú diskusiu, nakol’ko by takýto orgán na celoštátnej úrovni vôbec $\mathrm{v}$ našich podmienkach mal pôsobit' alebo by na druhej strane bolo vhodnejšie riešit' túto objektívne existujúcu potrebu prostredníctvom vytvorenia organizačných súčastí v jednotlivých organizáciách verejnej správy. Obdobné inštancie s celoštátnym významom sa osvedčili vo viacerých krajinách. Z koncepčného hl'adiska eventuálne možno zohl'adňovanie etického aspektu praxe verejnej správy celoštátne zastrešit' stálou alebo ad hoc zostavovanou skupinou či výborom odborníkov, ktorej dokumenty by mali odporúčací charakter. Súčasne by sa takáto inštancia mohla zaoberat' spracovaním minimálnych etických požiadaviek a prispiet' tak k precizovaniu prieniku etického a právneho normatívneho systému.

$\mathrm{Na}$ základe uvedeného je možné domnievat' sa, že dôsledne spracovaný etický kódex so všetkými jeho podstatnými náležitost'ami dokáže prispiet' k zlepšeniu zohl'adňovania etického aspektu praxe verejnej správy. Vo vzt’ahu k občanovi možno pozitíva komplementárneho pôsobenia etických noriem očakávat’ v skvalitnení správy veci verejných v zmysle nestrannosti, nezávislosti, transparentnosti, otvorenosti, sledovania verejného 
záujmu a predchádzania konfliktu záujmov. Predovšetkým transparentnost' a otvorenost' môže občana motivovat' $\mathrm{k}$ vyššej participácii na správe veci verejných. Práve z tohto dôvodu boli analyzované etické kódexy, ktoré sú verejnosti vol’ne dostupné. V opačnom prípade nie je potenciál kódexov plne využívaný. Verejnost’ by mala poznat' etický rozmer nárokov kladených na zamestnancov verejnej správy, pretože iba v tom prípade dokáže pôsobit' aj ako kontrolný prvok. Možno sa domnievat', že práve zamestnanec uvedomujúci si okrem iných aj etické dopady svojho správania sa, konania a rozhodovania na občana, môže prispiet’ k spokojnosti občana s poskytovanými verejnými statkami a službami. Súčasne môže zamestnanec správajúci sa v súlade so stanovenými etickými požiadavkami prispiet’ k zníženiu vnímanej miery korupcie.

\section{Záver}

Komplexnost' súčasnej spoločnosti 21. storočia spôsobuje stieranie rozdielov medzi správnym a nesprávnym správaním sa, konaním a rozhodovaním. Napriek množstvu noriem, zákonov, príkazov a pravidiel možno jednoznačne hovorit' o nevyhnutnosti regulácie zamestnancov jednotlivých subjektov verejnej správy. Nesprávne konanie a rozhodnutie zamestnancov verejnej správy môže mat' negatívny dopad na jednotlivca, skupiny, konkrétne územie alebo realizáciu verejného záujmu. Žiadna norma vytvorená človekom, bez ohl'adu na to či je právna, etická alebo iná, nie je dokonalá a z tohto pohl'adu je komplementárne pôsobenie normatívnych systémov viac ako žiadúce a opodstatnené.

Kým na jednej strane možno pozitívne vnímat' prekryv požiadaviek právneho a etického charakteru, súčasne je potrebné mat' na zreteli postavenie etiky ako regulátora správania sa, konania a rozhodovania jednotlivcov. Prioritne by etické normy mali slúžit' ako regulátor komplementárneho charakteru. Prostredníctvom etických kódexov je totiž možné detailne spracovat' požiadavky týkajúce sa konfliktu záujmov, prijímania darov, vzájomných interakcií medzi zamestnancami, nadriadenými a verejnost'ou, ale aj záležitosti týkajúce sa zneužívania právomoci alebo oznamovanie neprípustného konania. Vzhl'adom na aktuálny stav spoločnosti, ktorý je potrebné vnímat' v širšom celospoločenskom kontexte, možno oprávnene uvažovat' o uprednostňovaní právneho normatívneho systému. Pre oblast' verejnej správy v súčasnosti len vel’mi t’ažko možno hovorit' o rovnocennom postavení predmetných dvoch normatívnych systémov. Na druhej strane však dôraz na uplatňovanie noriem etického charakteru nie je v podmienkach Slovenskej republiky taký, aký by mal byt'.

Právne normy v podstate regulujú predmet záujmu etiky vo vernej správe len rámcovo a v najvšeobecnejších súvislostiach, respektíve nevenujú kategóriám ako transparentnost', nestrannost', otvorenost', integrita a zodpovednost' žiadnu pozornost'. Formulovaný ciel' sa podarilo naplnit' a stanovená hypotéza sa potvrdila. Domnievame sa, že hlavným zistením je skutočnost', že komplementárne pôsobenie predmetných dvoch 
normatívnych systémov môže výrazne prispiet' $\mathrm{k}$ dosahovaniu atribútov ako napríklad, transparentnost', otvorenost', nestrannost', nezávislost' alebo zodpovednost'. Z pohl’adu občana ide o dôležité faktory, ktoré popri kvalite a kvantite verejných statkov a služieb oprávnene od verejnej správy očakáva. Etické normy môžu byt’ významným faktorom, prostredníctvom ktorého je možné ovplyvnit' správanie sa zamestnancov verejnej správy a mali by byt' využívané ako komplementárny a dodatočný regulátor popri platnej a účinnej legislatíve. 